\title{
A Bíblia como Literatura
}

\author{
The Bible as Literature
}

\section{La Biblia como Literatura}

\author{
Profa. Dra. Luana Martins Golin* \\ * Universidade Metodista de São Paulo - UMESP \\ Mestra e doutora em Ciências da Religião pela \\ Submetido em: 23-3-2021 \\ Universidade Metodista de São Paulo, onde atua como \\ Aceito em:5-5-2021 \\ professora na Faculdade de Teologia, na modalidade \\ EAD e Lato Sensu. \\ luanamgolin@gmail.com
}

\begin{abstract}
RESUMO
Este artigo é resultado de uma palestra ministrada no Webinar: "Revisitando a Bíblia a partir de perspectivas modernas", organizado pela Faculdade de Teologia da Igreja Metodista, em junho de 2020. Trata-se de um tema que também foi desenvolvido em minha tese de doutorado em Ciências da Religião. A reflexão sobre Bíblia como literatura parte de importantes autores que discutem o tema, a saber: Eric Auerbach, Northrop Frye e Robert Alter. A artigo procurou demonstrar e exemplificar as características literárias da Bíblia e sua importância no diálogo com a cultura e outras literaturas.
\end{abstract}

Palavras-chave: Bíblia; literatura; narrativa; personagens; ambiguidades.

\begin{abstract}
This article is the result of a lecture given at the Webinar: "Revisiting the Bible from modern perspectives", organized by the Faculty of Theology of the Methodist Church, in June 2020. This is a topic that was also developed in my thesis of $\mathrm{PhD}$ in Sciences of Religion. The reflection on the Bible as literature comes from important authors who discuss the topic, namely: Eric Auerbach, Northrop Frye and Robert Alter. The article sought to demonstrate and exemplify the literary characteristics of the Bible and its importance in dialogue with culture and other literatures.
\end{abstract}

Keywords: Bible; literature; narrative; characters; ambiguities.

\section{RESUMEN}

Este artículo es el resultado de una conferencia impartida en el Webinar: "Revisando la Biblia desde perspectivas modernas", organizado por la Facultad de Teología de la Iglesia Metodista, en junio de 2020. Este es un tema que también se desarrolló en mi tesis de doctorado en Ciencias de la Religión. La reflexión sobre la Biblia como literatura proviene de importantes autores que discuten el tema, a saber: Eric Auerbach, Northrop Frye y Robert Alter. El artículo buscaba demostrar y ejemplificar las características literarias de la Biblia y su importancia en el diálogo con la cultura y otras literaturas.

Palabras-clave: Biblia; literatura; narrativa; personajes; ambigüedades. Introdução: a Palavra criadora de mundos

"No coração do processo criativo, há um paradoxo religioso. Nenhum homem é mais inteiramente lavrado à imagem e semelhança de Deus ou mais inevitavelmente do que Seu desafiante, o poeta."

(George Steiner) 
"No princípio, criou Deus os céus e a terra. A terra, porém, estava sem forma e vazia; havia trevas sobre a face do abismo, e o Espírito de Deus pairava por sobre as águas.

Disse Deus: Haja luz; e houve luz."

(Gênesis 1.1-3)

“Deus diz 'Paraíso!', e um jardim de delícias aparece; a bruxa diz 'sapo!', e o príncipe se transforma em sapo.”

(Rubem Alves)

Deus-Poietés, Deus que cria mediante a palavra, verbo em movimento que gera existência ao inexistente. Encontros de beleza, poesia e vida. Há algo em comum entre o poeta e Deus, ou algo divino no poeta.

Deus cria por meio da palavra, a palavra nomeada se materializa e ganha existência. É como uma palavra mágica pronunciada. Assim como o Elohim de Gênesis 1 e o Adão de Gênesis 2, a missão do poeta é nomear o mundo. O poeta não descreve, mas apresenta, recria, revive. A poesia é o lugar onde nomear é ser; onde nomes e coisas se fundem e são o mesmo; onde se diz o indizível e o paradoxo. Poetizar é criar com palavras, nomear o que só existia como ameaça, vazio e caos. As palavras não estão nos esperando, mas é preciso criá-las e inventá-las.

Deus e o ser humano concorrem, ambos são poetas e criadores. Rubem Alves dirá que "as palavras podem ser matéria-prima com que se constroem mundos" (ALVES, 1992, p. 57). A religião se expressa em linguagem metafórica-poética e ficcional. A criação literária é uma possibilidade aberta, criadora de mundos, geradora de sentidos.

\section{A Bíblia como literatura a partir de Eric Auerbach}

Um dos pioneiros na análise literária da Bíblia foi Eric Auerbach, em seu famoso artigo "A cicatriz de Ulisses" (2009), no qual propõe uma comparação entre o estilo homérico na "Odisseia" e o sacrifício de Isaque narrado em Gênesis 22, ou seja, entre a literatura clássica grega e a literatura hebraica antiga. Auerbach pontua as principais diferenças entre o texto bíblico, que é lacunar e dá margens à imaginação e interpretação do leitor, e a épica grega, cujo caráter é mais descritivo e analítico. Em Homero, há uma minuciosa descrição dos eventos exteriores sem descontinuidades e sem ambiguidades; já o estilo bíblico parece enigmático e abrupto. Para os heróis de Homero, as situações complexas seriam incompreensíveis; em contrapartida, o texto bíblico tem o potencial de condensar em si o trá- 
gico, o sublime, o problemático em meio a uma realidade doméstica. Em "A cicatriz de Ulisses", tudo é relatado com exatidão, num discurso direto, pormenorizado, com espaço e tempo abundantes e clareza de detalhes, "não deixando nada no escuro e sem omitir nenhuma das articulações que as ligam entre si" (AUERBACH, 2009, p. 2). Há uma riqueza de imagens idílicas. Homero não conhece segundos planos, mas somente a presença do primeiro plano: "o que ele nos narra é sempre somente presente, e preenche completamente a cena e a consciência do leitor" (AUERBACH, 2009 , p. 3). Assim, nada fica na penumbra ou inacabado. O texto apresenta transparência e claridade, uniformidade e falta de tensão na narrativa: “(...) sem que se mostre, em parte alguma, uma forma fragmentária ou só parcialmente iluminada, uma lacuna, uma fenda, um vislumbre de profundezas inexploradas" (AUERBACH, 2009, p. 4). Em Homero, tudo é iluminado, definido e acabado no tempo e no espaço. Em contrapartida, a narrativa bíblica apresenta obscuridade, escuridão, inexpressão, presença de tempo e espaço indefinidos, discursos fragmentários, tensões e a presença do segundo plano. Na narrativa de Gênesis 22, os dois interlocutores, Deus e Abraão, não estão num mesmo plano. A viagem de três dias é feita, mas nada é dito sobre ela. Isaque surge como um terceiro personagem importante. É notória uma tensão opressiva no relato da oferenda de Abraão. Deus dá sua ordem em discurso direto, mas não diz seus motivos e intenções. Abraão recebe a ordem, calado, e age da maneira como lhe foi ordenado. Isaque rompe o silêncio na narrativa, gerando uma tensão. Sentimentos e pensamentos ficam inexpressos. O Deus bíblico se estende para as profundidades. "Os próprios seres humanos dos relatos bíblicos são mais ricos em segundos planos do que os homéricos; eles têm mais profundidade quanto ao tempo, ao destino e à consciência" (AUERBACH, 2009, p. 9). Nesse sentido, com a multiplicidade de camadas dentro de cada ser humano, a antropologia hebraica é mais complexa do que a homérica:

Os autores judeus conseguem exprimir as camadas simultaneamente sobrepostas da consciência e o conflito entre as mesmas. Os poemas homéricos, cuja cultura sensorial, linguística e, sobretudo, sintática, parece ser tanto mais elaborada, são, contudo, na sua imagem do homem, relativamente simples. (AUERBACH, 2009, p. 10).

A Bíblia consegue evocar personagens com profundidade e complexidade, utilizando-se de meios aparentemente simples. Muitos personagens bíblicos ficaram gravados na imaginação de gerações como pessoas vivas. Personagens inacabados, reticentes, opacos, ambíguos, que se transformam ao longo do tempo e da narrativa, que são mutáveis, imprevisíveis e não fi- 
xados. Aqui se pode citar o exemplo de Jacó e Davi - personagens que não são planos, mas esféricos, cheios de surpresas:

O conceito de personagem implícito na Bíblia - uma figura muitas vezes imprevisível, até certo ponto impenetrável, que constantemente emerge das sombras da ambiguidade e para elas retorna - tem mais afinidade com certas noções modernas do que os modos de caracterização típicos dos poemas épicos gregos. (...) A arte narrativa da Bíblia significa, portanto, mais que um empreendimento estético, e aprender ler suas modulações mais finas pode nos aproximar, com mais precisão que os conceitos amplos da história das ideias e das religiões, de uma estrutura imaginativa a cuja sombra ainda vivemos. (ALTER, 2007, p. 196).

Os personagens bíblicos não são fixos e definidos como os grandes heróis da épica grega e latina. Ao contrário, os personagens bíblicos sofrem grandes mutações.

Para Auerbach, é possível analisar Homero, mas não interpretá-lo. Já o leitor da narrativa bíblica sabe que Deus é oculto e, por isso, pode interpretá-lo. O leitor insere sua própria vida no mundo da narrativa e se sente membro de uma estrutura histórico-universal, com início e fim, com uma temporalidade mítica atemporal. A narrativa bíblica não tenta harmonizar e simplificar para evitar conflitos. Nos relatos do Antigo Testamento, o sublime, o trágico e o problemático se formam no quotidiano (por exemplo, Caim e Abel, Noé, Abraão, Sara e Hagar etc.). Em resumo:

Os dois estilos representam, na sua oposição, tipos básicos: por um lado, descrição modeladora, iluminação uniforme, ligação sem interstícios, locução livre, predominância do primeiro plano, univocidade, limitação quanto ao desenvolvimento histórico e quanto ao humanamente problemático; por outro lado, realce de certas partes e escurecimento de outras, falta de conexão, efeito sugestivo do tácito [silencioso, secreto, implícito], multiplicidade de planos, multivocidade e necessidade de interpretação, pretensão à universalidade histórica, (...) e aprofundamento do problemático. (...) Foi em seu pleno desenvolvimento alcançado em seus primórdios que esses estilos exerceram sua influência constitutiva sobre a representação europeia da realidade. (AUERBACH, 2009, p. 20).

A multiplicidade de planos ou a multivocidade está presente na literatura bíblica. Para Alter, os escritores bíblicos estão interessados em como os personagens praticam ou regem as ações, e o uso do discurso direto é um instrumento muito importante de revelação dos personagens. A preferência do escritor bíblico pelo discurso direto aponta para o diálogo e as vozes de personagens. "Tudo no universo da narrativa bíblica gravita em direção ao diálogo" (ALTER, 2007, p. 268). Muitas vezes, o discurso do personagem é apresentado como um monólogo interior, como um pensamento falado. 
A prosa é também um elemento importante na literatura bíblica. Para Alter, os escritores bíblicos estão entre os pioneiros da prosa de ficção na tradição literária ocidental. "Os narradores das histórias bíblicas são naturalmente 'oniscientes', e esse termo teológico transferido para a técnica narrativa tem para eles uma razão de ser especial" (ALTER, 2007, p. 234). A prosa deu aos escritores flexibilidade e diversidade de recursos narrativos:

(...) A escrita bíblica recusa a circularidade estável do mundo mitológico e se abre à indeterminação, às variáveis causais, às ambiguidades de uma ficção elaborada para se aproximar das incertezas da vida na história. E eu acrescentaria que, nesse movimento, a flexibilidade da prosa como meio narrativo era indispensável, pelo menos no contexto do Oriente Próximo. (ALTER, 2007, p. 50. Grifo meu).

Os autores bíblicos, ao utilizarem a ficção em prosa, deixaram um legado cultural. O quadro abaixo resume a análise feita por Auerbach:

\begin{tabular}{|l|l|}
\hline \multicolumn{1}{|c|}{ Homero } & \multicolumn{1}{c|}{ Bíblia } \\
\hline Descrição minuciosa & Lacunas \\
\hline Sem descontinuidades e ambiguidades & Enigmático e abrupto \\
\hline Sem complexidades & $\begin{array}{l}\text { Trágico, sublime, problemático em } \\
\text { meio a uma realidade doméstica }\end{array}$ \\
\hline $\begin{array}{l}\text { Espaço e tempo abundantes, clareza } \\
\text { de detalhes. Não conhece } 2^{\circ} \text { plano. }\end{array}$ & $\begin{array}{l}\text { Obscuridade, presença do tempo e } \\
\text { espaço indefinidos. } 2^{\circ} \text { plano }\end{array}$ \\
\hline Uniformidade & Discursos fragmentados \\
\hline Falta tensão narrativa & Apresenta tensões \\
\hline Definido e acabado & $\begin{array}{l}\text { Inacabado, inconcluso, cheio de pro- } \\
\text { fundidades }\end{array}$ \\
\hline Antropologia mais simples & Antropologia mais complexa \\
\hline $\begin{array}{l}\text { Personagens planos ou tipológicos } \\
\text { (herói) }\end{array}$ & $\begin{array}{l}\text { Personagens esféricos: mutáveis, im- } \\
\text { previsíveis e não fixados }\end{array}$ \\
\hline Permite a análise & $\begin{array}{l}\text { Permite a interpretação, em diálogo } \\
\text { com o leitor }\end{array}$ \\
\hline Univocidade & \begin{tabular}{l} 
Multivocidade \\
\hline
\end{tabular}
\end{tabular}

\section{A Bíblia como literatura a partir de Northrop Frye}

Em seu livro, "O código dos códigos - a Bíblia e a Literatura” (2004), Frye faz uma leitura da Bíblia sob o ponto de vista de um crítico literário. Para ele, a Bíblia influenciou toda a tradição literária e cultural do Ocidente, daí sua extrema importância enquanto texto literário. O que o autor pretende 
em seu livro é apresentar uma estrutura unificada das imagens e da narrativa bíblica e ressaltar o valor do texto bíblico enquanto literatura. Para ele:

A abordagem da Bíblia de um ponto de vista literário não é per si ilegítimo: nenhum livro poderia ter uma influência literária tão pertinaz sem possuir, ele próprio, características de obra literária. (...) Parece-me que alguém de fora do círculo de especialistas precisa chamar a atenção para a existência e a relevância da Bíblia. (...) De que a Bíblia é relevante para a literatura secular. (FRYE, 2004, p.14 e 18. Grifo meu).

Frye valoriza a riqueza do texto bíblico enquanto literatura. Ele não apenas entendeu o texto bíblico na categoria de texto literário como procurou fazer uma análise literária da Bíblia, rompendo com perspectivas que tendem a negligenciar, ocultar e reduzir o seu valor:

A reação normal dos homens diante de um grande feito cultural como a Bíblia é fazer o que os filisteus fizeram a Sansão: reduzi-lo à impotência, então fechá-lo num moinho para espremer nossas agressões e preconceitos. Mas talvez seus cabelos, como os de Sansão, possam crescer mesmo aí. (FRYE, 2004, p. 272. Grifo meu.).

A estrutura do texto bíblico é complexa, composta por narrativas, imagens e metáforas, tipos e antítipos. A análise de Frye ajuda a perceber que a Bíblia não é fechada e definida, mas aberta e livre. Ela abre espaço para muitas reflexões e transformações. Nela, uma coisa pode vir a ser outra coisa.

Frye dirá que o texto bíblico não está preocupado com "fatos" e histórias verídicas, mas com o significado espiritual expresso nas narrativas. Nessa perspectiva, nem o Antigo Testamento ou Bíblia Hebraica é história, nem os Evangelhos são biografias, pois a preocupação última do texto bíblico está em seu sentido espiritual e não histórico. A Bíblia está interessada na história da salvação, na história das ações de Deus no mundo e na relação do ser humano com essa história. Robert Alter (2007), outro importante estudioso da narrativa bíblica, faz uma pergunta crucial:

Se o texto é tido como sagrado, como explicá-lo em categorias literárias seculares e estéticas? E se o texto é histórico, destinado a explicar a experiência nacional dos israelitas, como ler tais narrativas como prosas de ficção? Não estaríamos forçando a Bíblia a ser 'literatura' quando tentamos transferir essas categorias à análise de um conjunto de textos de motivação teológica, de sentido histórico e decorrentes, em certa medida, de um trabalho de composição coletiva? (...) A história tem relações muito mais estreitas com a ficção do que em geral se supõe. (...) O caso da Bíblia, como história sagrada é, no entanto, bem diferente da situação da historiografia moderna. (ALTER, 2007, p. 45). 
No universo bíblico, há uma relação intrínseca entre história e ficção, pois a ficção era o principal recurso disponível aos escritores bíblicos para compreender a história. Contudo, com a modernidade, o empirismo racional requer que se faça uma escolha: ou a Bíblia é um registro de história, ou incorpora uma mensagem simbólica. As duas concepções passaram a ser vistas como mutuamente contraditórias e excludentes.

Geralmente, a Bíblia não é lida como literatura, embora tenha características de texto literário e seja literatura. Por esse motivo, ela tende a ser lida como se fosse uma linguagem puramente descritiva. Tradicionalmente, a Bíblia foi lida como literalmente histórica e seu significado como doutrinal ou didático. Não se deu a devida atenção às narrativas, poesias e profecias bíblicas como literatura. Contudo, de acordo com a perspectiva literária de Frye, ao contrário do que se afirma tradicionalmente, as bases literais de sustentação da narrativa bíblica são o mito e a metáfora. Ler a Bíblia como literatura é redundante, assim como falar em ler Dante como literatura. Até mesmo os personagens bíblicos históricos são tratados de forma ficcional. As histórias de Davi são bons exemplos da relação existente entre história e ficção. Como sugere Alter, os escritores hebreus buscavam revelar, por meio do processo narrativo, os eventos e propósitos divinos nos acontecimentos históricos. Nessa dinâmica surgem duas tensões dialéticas: por um lado, a vontade, o propósito e a condução divina; do outro, a natureza e a liberdade humana.

Para Frye, a Bíblia é um texto que vai se revelando e segue numa sequência dialética. Nessa progressão, identificam-se sete fases principais: 1) Criação; 2) Revolução ou Êxodo; 3) Lei; 4) Sabedoria; 5) Profecia; 6) Evangelho; 7) Apocalipse. Como segue:

1) Criação: A primeira fase assinala o início da narrativa bíblica com o tema da criação do mundo. Frye diz que o texto bíblico descreve uma criação artificial, pois aquele que concede a vida é uma figura masculina. O fato de o texto bíblico apresentar um pai criador rivaliza com muitos mitos de criação sexual que, geralmente, são associados a uma figura feminina, a "mãe-terra". Nos mitos de criação, destacam-se três pontos: a) o objeto a ser criado; b) a fonte ou material utilizado na criação; e c) o sujeito criador. $\mathrm{Na}$ narrativa bíblica, é o poder criador das palavras verbalizadas que gera vida ao que não existe, o que difere do pensamento de culturas da época, nas quais as coisas são criadas sempre a partir de alguma coisa que já existe. A criação mítica bíblica é vista como a passagem de um estado amorfo (caos) para a criação (cosmo). O caos geralmente está associado às trevas ou noite, como vazio ou abismo, como água ou desordem da água e do fogo, como um estado amorfo 
da substância. Já o cosmo está associado à ordem, à harmonia, ao equilíbrio. O castigo associa-se ao declínio. O episódio bíblico interpretado como uma queda (Gênesis 3) revela o movimento da transformação da ordem (paraíso) para o caos (pecado e expulsão do paraíso). A queda revela o contraste entre o mundo perfeito criado por Deus e o mundo que agora é habitado. Os arquétipos do caos e das trevas podem ser vistos como inimigos de Deus, como seres que estão fora da criação, ou como criaturas de Deus. A Criação apresenta uma metáfora de integração da parte com o todo. O cristianismo procurou manter um equilíbrio entre o desprezo gnóstico pela natureza e a "adoração pagã " por ela. Nesse sentido, criou categorias como "boa criação", a criação descrita em Gênesis antes da queda e a "criação inferior", após a queda. Assim, o ser humano nasce no nível inferior e seu dever é elevar-se ao nível superior, num retorno ao Éden. Assim, a Criação é um tipo, cujo antítipo é o novo céu e a nova terra prometidos no Apocalipse 21.1: "E vi um novo céu, e uma nova terra. Porque já o primeiro céu e a primeira terra passaram (...)". Nos mitos escatológicos, a $\square$ idade de ouro $\square$ está, novamente, por vir. Em outras palavras, é a retomada do estado original, da ordem primeira que fora perdida.

Sobre a temática da Criação, em perspectiva literária, é importante destacar a análise feita por Haroldo de Campos (2000), em seu livro "Bere'shith - a cena da origem (e outros estudos de poética bíblica)". Nesse livro, o autor traduz e comenta, de maneira criativa e poética, a narrativa da criação em Gênesis 1, destacando o aspecto pneumático ou de respiração da língua hebraica, cheia de efeitos onomatopaicos, jogos sonoros e de palavras, além da obscuridade oracular da poesia e a forma paralelística típica da escritura bíblica: "nestes versículos inaugurais do Bere'shith, condensa-se, no seu todo e em suas partes, a saga da criação, como um Deus-Poietés, metafórico e metonímico - Il Fattore dantesco, el Hacedor borgiano" (CAMPOS, 2000, p. 36).

2) Revolução ou Êxodo: este item propõe uma discussão sobre a questão da teodiceia. Se o relato do livro do Éxodo começasse a partir do diálogo com Moisés na sarça ardente (Êxodo 3), ocultaria o sofrimento do povo hebreu descrito nos dois primeiros capítulos do mesmo livro. Contudo, o escritor e o editor do livro fizeram questão de descrever tanto o sofrimento vivido pelos israelitas como sua libertação. Se a teodiceia ainda é um problema e uma inquietação teológica e filosófica, o texto bíblico não quis ocultá-la. No livro do Exxodo, Moisés aparece como um personagem central. Todo o Antigo Testamento está pautado pelo sentido da audição e não da visão. Deus não pode ser representado em imagens ou visto por alguém. O aspecto revolucionário se dá na palavra escutada da parte de Deus e levada à ação. 
3) A Lei: Para Frye, o editor bíblico foi bastante coerente ao situar a lei após o êxodo. Essa sequência é correta tanto do ponto de vista lógico quanto psicológico. Levando-se em conta que a fase anterior trata de uma revolução, da saída de um povo escravo para uma terra própria, era necessário o estabelecimento de uma lei. Ao conduzirem o povo, Moisés e Josué estabeleceram uma ditadura teocrática, na qual qualquer ameaça ou rebelião foi contida (por exemplo, o relato da rebeldia de Acã, em Josué 7). A lei de Talião possivelmente influenciou o pensamento grego acerca da ideia de nemesis, ou seja, a tendência que a natureza tem para recuperar seu equilíbrio após um ato humano de agressão ou desequilíbrio.

4) A Sabedoria: relaciona-se com o passado, com a ideia de continuidade e persistência no comportamento correto. Nesse sentido, ela procura manter a ordem e a tradição. A literatura sapiencial tem como cerne o provérbio, cultivado por todas as civilizações do Oriente próximo. O centro da concepção de sabedoria na Bíblia é o Eclesiastes, também chamado de Kohelet. O tema da vaidade aparece ao longo de todo o texto. Hebel, palavra hebraica que foi traduzida por "vaidade", significa "neblina", "cerração" e "vapor". Seu sentido é derivado de "vazio"; é como se todas as coisas estivessem plenas de vazio. A expressão Plenas de vazio é um paradoxo importante no texto bíblico. Portanto, a grande sabedoria de Eclesiastes é compreender que nada é novo e, então, viver com intensidade, a fim de que tudo se torne novo. A névoa ou cerração existente em "vaidade" é uma metáfora que sugere que a vida é algo através do qual devemos encontrar um caminho, e que a sabedoria é a chave da saída. (Cf. FRYE, 2004, p. 155-157).

5) Profecia: a maioria dos profetas dos tempos bíblicos era composta de funcionários bem estabelecidos da corte ou do templo. Contudo, o profeta autêntico era aquele que tinha a mensagem impopular e dizia não o que a corte ou o rei queriam ouvir, mas o que Deus mandava dizer. ${ }^{1}$ Nesse sentido, a autoridade profética é mais radical e se diferencia da autoridade sacerdotal. Muitos associam o profeta a um vidente, como alguém que pode predizer ou ver o futuro. Entretanto, os profetas bíblicos falam de um futuro muito próximo. A profecia incorpora e amplia a perspectiva da Sabedoria. É diferente a maneira como um sábio e um profeta pensam a situação humana. $O$ sábio pensa a situação humana como uma linha horizontal, formada pelo precedente, pela tradição, e avançando graças à prudência. Já o profeta enxerga o ser humano

É importante destacar que nem todo profeta da corte e do templo era ilegítimo e "oportunista", por exemplo: Samuel, Natã e Isaías profetizaram durante alguns momentos de suas vidas na corte. 
em estado de alienação, como se estivesse num ponto mais baixo de uma curva em forma de " $U$ ”. $\mathrm{Na}$ estrutura em " $U$ ", há um momento inicial, de equilíbrio. Contudo, o equilíbrio é atingido, por algum motivo, e gera uma queda ou desequilíbrio. Em seguida, ocorre uma restauração ou retorno ao estágio inicial.

A partir deste ponto de vista, é possível perceber que o Livro de Jó, embora seja classificado como literatura sapiencial, também pode ser compreendido sob uma perspectiva profética, pois sua estrutura segue, claramente, uma curva em forma de "U". Jó não segue a linha horizontal da prudência e do precedente. Jó não se enquadra, narrativamente, na perspectiva da Sabedoria, pois, mesmo observando a lei e a justiça ele não foi poupado da dor e do sofrimento. A estrutura de Jó segue mais a forma em "U”, da prosperidade inicial, da humilhação e queda, e depois do retorno. O elemento profético nesse livro tem relação com sua forma narrativa.

6) Evangelho: Neste item, Frye apresenta o tema da Encarnação de Jesus Cristo como um movimento descendente-ascendente. Descendente, porque Cristo teria deixado a eternidade, habitado o tempo e baixado à Terra. Ascendente, porque o Messias teria vencido a morte e subido novamente aos céus. A figura do Emanuel - Deus Conosco (cf. Isaías 7) e a descrição dos ossos secos que tornam a ter vida (cf. Ezequiel 37) são tipos do AT da encarnação e da ressurreição de Jesus.

Para o cristianismo, o AT é visto como profecia e não como lei, nesse sentido, difere-se significativamente da perspectiva judaica. Os Evangelhos, nesse sentido, são o cumprimento de profecias anunciadas anteriormente. Muitas vezes se atribui à vida de Jesus um significado puramente moral. Entretanto, Frye destaca o papel profético de Jesus na sociedade de seu tempo. Não há sociedade humana que tolere profetas e que não os rejeite:

A sociedade que o rejeitou [a Jesus] representa todas as sociedades; os responsáveis por sua morte não foram os romanos ou os judeus ou qualquer outro povo que ali estivesse incidentalmente, mas o conjunto da humanidade, que se estende até nós e certamente vai muito além. 'Convém que um homem morra pelo povo', é o que diz Caifás (Jo 18.14), e nunca houve sociedade humana que não concordasse com ele. (FRYE, 2004, p. 165. Grifo meu).

7) Apocalipse: A última fase trata do livro do Apocalipse ou revelação. Revelar é descobrir o que está coberto ou retirar um véu. O Apocalipse apresenta uma progressão de antítipos. Nele, o povo de Deus alcança um estado de reconhecimento, enquanto os "reinos pagãos" permanecem nas trevas. A narrativa bíblica revela que Deus, no princípio, criou um mundo bom, porém, com a queda, a natureza foi corrompida. A nostalgia do paraíso 
perdido e o desejo de retornar para ele perpassam a história bíblica. Mito e história se entrelaçam nos apocalipses. O livro contém uma apresentação cíclica de visões que se repetem ou recapitulam. Perseguição presente, destruição iminente dos maus e recompensa dos justos. Ao final do livro, com frases como "faço eu novas todas as coisas" (Ap 21.5), e com a promessa de um novo céu e de uma nova terra, o retorno ao jardim é alcançado. Assim, Gênesis torna-se o tipo, e o Apocalipse, o antítipo:

Ao serem expulsos do Paraíso, Adão e Eva perdem a árvore e a água da vida, e ao final da Bíblia ambas são restauradas para uma humanidade redimida (Ap 22.1-2). Estas duas imagens são, portanto, as indicações mais evidentes de haver um começo e um fim na narrativa bíblica, enquanto imagens de um mundo que o homem perdeu, mas que deverá, ao fim e ao cabo, recuperar. (FRYE, 2004, p. 178).

A recepção do Apocalipse foi bastante significativa na arte e na literatura, desde os tempos antigos. O Apocalipse é uma criação imaginativa e simbólica, uma obra de literatura e não um manual sobre os eventos do fim.

Após dividir o texto bíblico em sete fases, Frye dedica-se a analisar as imagens metafóricas bíblicas. Dois níveis da natureza aparecem na Bíblia: o inferior e o superior. Frye apresenta dois mundos com imagens características: o mundo apocalíptico ou ideal (natureza superior) e o mundo demoníaco (natureza inferior). Para cada imagem apocalíptica ou idealizada da Bíblia tem uma contrapartida demoníaca. Sua análise está pautada nos pares de oposição. A seguir, o esquema das imagens bíblicas apocalípticas (Cf. FRYE, 2004, p.202.)

\begin{tabular}{|l|l|l|}
\hline \multicolumn{1}{|c|}{ Categoria } & Forma em classe ou grupo & \multicolumn{1}{c|}{ Individual } \\
\hline Divino & ${\text { [Trindade }{ }^{2}}^{\text {Espiritual ou }} \begin{array}{l}\text { Angelical } \\
\text { 1) Espíritos do fogo: Se- } \\
\text { rafim e 2) Espíritos do ar: } \\
\text { Querubim }\end{array}$ & $\begin{array}{l}\text { Espírito como Fogo; } \\
\text { Espírito como Pomba ou } \\
\text { Vento }\end{array}$ \\
\hline Paradisíaco & Jardim do Éden & Árvore e Água da vida \\
\hline Humano & Povo como noiva (Israel) & Noivo \\
\hline Animal & Aprisco ou rebanho & $\begin{array}{l}\text { 1) Pastor, 2) Cordeiro - } \\
\text { Corpo e sangue }\end{array}$ \\
\hline Vegetal & Colheita e vindima & Pão e vinho, primícias \\
\hline Mineral & $\begin{array}{l}\text { Cidade (Jerusalém) } \\
\text { e estradas }\end{array}$ & Templo; Pedra \\
\hline
\end{tabular}

2 A palavra Trindade não aparece na Bíblia, contudo, é um conceito teológico aceito no cristianismo. 
$\mathrm{Na}$ análise de Frye, todas as categorias individuais são identificadas com Cristo, ou seja, Cristo é: Deus, Espírito, árvore da vida, pastor, cordeiro, pão, vinho, templo etc. A imagem de Cristo adquire inúmeros significados metafóricos. A seguir, o esquema das imagens demoníacas bíblicas (Cf. FRYE, 2004, p. 203):

\begin{tabular}{|c|c|c|c|}
\hline \multirow{2}{*}{ Categoria } & \multirow{2}{*}{ Manifesto Demoníaco } & \multicolumn{2}{|l|}{ Demoníaco Paródico } \\
\hline & & Grupo & Individual \\
\hline Divino & [Satã $]$ & $\begin{array}{l}\text { Stoicheia } \\
\text { Tou Kosmou }\end{array}$ & Anticristo \\
\hline $\begin{array}{l}\text { Espiritual } \\
\text { ou } \\
\text { Angelical }\end{array}$ & $\begin{array}{l}\text { 1. Espíritos do Fogo } \\
\text { 2. Demônios da Tem- } \\
\text { pestade }\end{array}$ & Falsos deuses & $\begin{array}{l}\text { Moloc, Baal, } \\
\text { Dagon etc. }\end{array}$ \\
\hline Paradisíaco & $\begin{array}{l}\text { Terras devastadas e } \\
\text { Mar da Morte }\end{array}$ & \multicolumn{2}{|c|}{ Árvore e Água do poder pagão } \\
\hline Humano & Os Expelidos & $\begin{array}{l}\text { "Grande Prostituta" } \\
\text { (Os reinos pagãos) }\end{array}$ & $\begin{array}{l}\text { Nero, Nabu- } \\
\text { codonosor e } \\
\text { Antíoco }\end{array}$ \\
\hline Animal & $\begin{array}{l}\text { Dragões do Caos } \\
\text { (Leviatã, etc.) }\end{array}$ & $\begin{array}{l}\text { Feras de rapina ou } \\
\text { de Fertilidade }\end{array}$ & $\begin{array}{l}\text { Animais } \\
\text { Divinizados } \\
\text { (Touro, Ser- } \\
\text { pente) }\end{array}$ \\
\hline Vegetal & $\begin{array}{l}\text { Colheita ou } \\
\text { Vindima da Ira }\end{array}$ & \multicolumn{2}{|c|}{ Deuses da Vegetação e Mães-Terra } \\
\hline Mineral & Ruínas & $\begin{array}{l}\text { Cidade Pagã } \\
\text { Roma ou Babilônia }\end{array}$ & $\begin{array}{l}\text { Torre de } \mathrm{Ba}- \\
\text { bel }\end{array}$ \\
\hline
\end{tabular}

Frye destaca a estrutura da narrativa bíblica em forma de "U", como no livro dos Juízes que apresenta, repetidamente, a apostasia e a restauração de Israel:

(...) este modelo em U, mesmo por aproximação, é recorrente em literatura como a forma comum da comédia. (...) A Bíblia em seu conjunto, vista como uma "divina comédia", está contida numa história em forma de U. Nela, o homem perde a água e a árvore da vida no começo do Gênesis e os recupera no fim do Apocalipse. (FRYE, 2004, p. 206).

A narrativa em "U” também estrutura o conceito de Encarnação de Jesus. Cristo "desceu” do céu para nascer na terra; atravessou seu ministério na terra e retornou ao céu. Frye estrutura todo o texto bíblico numa sequência em forma de "U", como ciclo de ascensão-queda. A seguir, os exemplos citados por ele (Cf. FRYE, 2004, p. 208):

3 Poderes da natureza, sempre que sejam tomados como numinosos, com poderes independentes dos humanos, ao invés de criaturas de Deus, forças escravizantes (FRYE, 2004, p. 200). 


\begin{tabular}{|l|l|}
\hline \multicolumn{1}{|c|}{ Ascensão (Ponto Alto) } & \multicolumn{1}{c|}{ Queda (Ponto Baixo) } \\
\hline Éden & Deserto, mar, cidade de Caim, Ur \\
\hline Terra Prometida I (Pastoral) & Egito, mar, deserto, Faraó \\
\hline Terra Prometida II (Agrícola) & Filisteus etc. \\
\hline Jerusalém, Monte Sião & Babilônia, Nabucodonosor \\
\hline Templo Reconstruído & Antíoco Epifânio \\
\hline Templo Purificado (Macabeus) & Roma, Nero \\
\hline Reino Espiritual de Jesus & \\
\hline Messias do judaísmo & Roma, Nero \\
\hline
\end{tabular}

Para ele:

Todos os pontos altos e os pontos baixos estão relacionados metaforicamente uns aos outros em sua categoria. Ou seja, o Jardim do Éden, a Terra Prometida, Jerusalém e o Monte Sião são sinônimos da morada da alma; em termos de imagética cristã, são idênticos em sua forma “espiritual” (...) ao reino de Deus de que Jesus falava. Do mesmo modo, o Egito, a Babilônia e Roma são espiritualmente o mesmo lugar; o Faraó do Exxodo, Nabucodonosor, Antíoco Epifânio e Nero são, espiritualmente, a mesma pessoa. Os libertadores de Israel: Abraão, Moisés e Josué, os Juízes, Davi e Salomão são todos protótipos do Messias - o libertador definitivo. (FRYE, 2004, p. 208).

Sob o ponto de vista narrativo, a Bíblia cristã possui um herói, o Messias. Tal como nas estórias romanescas, esse herói se apresenta com seu próprio nome e sua identidade apenas perto do final.

No Novo Testamento, Jesus é Salvador tanto como Messias judaico quanto como herói cultural greco-romano. Jesus ensinando no templo aos doze anos de idade pode ser visto como um topos biográfico grego, pois um grande homem deveria ter uma infância prodigiosa. Complementarmente, Frye apresenta um esquema circular da história do Messias que segue na seguinte ordem: Céu, Criação, Encarnação, Morte, Descida ao Inferno, Abertura do Inferno, Ressurreição, Ascensão, retorno ao Céu (Cf. FRYE, 2004, p. 212).

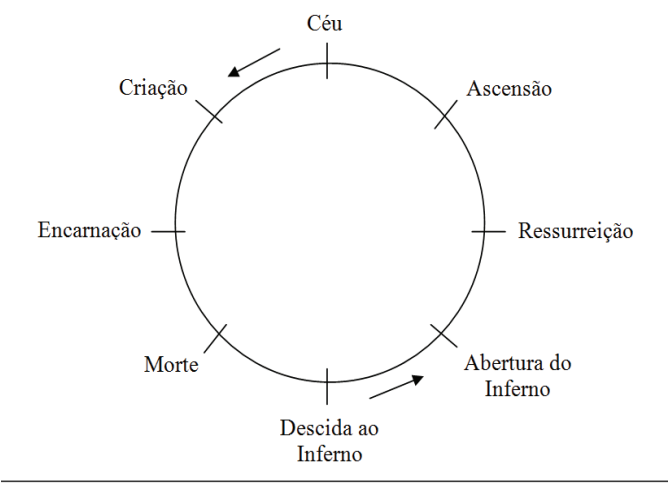


Para os cristãos, Deus assumiu as categorias humanas, humanizando-se. Assim, em Cristo Jesus, a Transcendência se fez Imanência. Em Cristo, Deus se torna humano para que os seres humanos possam participar de sua natureza divina.

A análise proposta por Frye, leva em consideração a Bíblia como um todo, como uma unidade bem estruturada, ainda que composta por muitos livros. O tema da unidade entre os textos leva a uma discussão sobre o cânon bíblico. A própria Bíblia faz referência a si mesma, a bíblia cita a bíblia, como uma intratextualidade. O cânone bíblico é um sistema intertextual. O todo é também uma unidade.

Frye afirma que enquanto outros povos se preocupavam com grandes edifícios, os israelitas produziram um livro e o valor que os hebreus deram ao texto parece ser único. É um fenômeno peculiar e culturalmente significativo que, entre os povos antigos, somente o de Israel tenha escolhido expressar suas tradições nacionais em prosa:

A supremacia do verbal sobre o monumental parece ter em si algo da supremacia da vida sobre a morte. Qualquer forma individual de vida pode ser aniquilada pelo menor incidente, mas a vida como conjunto [as palavras reunidas] tem um poder de sobrevivência que é maior do que o de qualquer coleção de pedras. (FRYE, 2004, p. 238).

Na narrativa bíblica, tudo o que é relatado ou escrito é essencial. Como parte da discussão, Frye toca em dois pontos: a autoria e a inspiração da Bíblia. Para ele, o texto bíblico é autêntico, independentemente de quem tenha sido seu escritor, pois o texto bíblico não está preocupado com a autoria, como estão os escritores e leitores modernos:

\footnotetext{
"autoria": eis aí uma concepção de pouca importância na composição da Bíblia, o que também descarta coisas como "inspiração" (...) Se a Bíblia for "inspirada” em algum sentido, seja no sagrado ou no secular, este conceito deve se estender necessariamente aos processos de edição, consolidação, redação, colagem, comentário e expurgo. (...) Também é fútil a tentativa de distinguir o que na Bíblia é "original”, as vožes de seus grandes gênios proféticos e poéticos, daquilo que nela seria acréscimo ou corruptelas supostamente postos à volta. Seus editores estão muito além de nossas possibilidades para que possamos enfrentá-los: pulverizaram a Bíblia a tal ponto que a noção de individualidade ali não tem o seu lugar. (FRYE, 2004, p. 241. Grifo meu).
}

Assim, percebe-se que a Bíblia é heterogênea como um mosaico; ela é polissêmica. O texto bíblico apresenta descontinuidades, duplicações e contradições que não se harmonizam facilmente com as hipóteses da unidade literária moderna. Essa diferença não descaracteriza o valor da literatura 
bíblica. Os relatos aparentemente contraditórios, atribuídos por muitos exegetas como oriundos de diversas fontes, não estão simplesmente justapostos, mas são complementares, pois ressaltam dimensões distintas de um mesmo assunto e têm a sua razão de ser na estrutura narrativa. O escritor/editor hebreu teve o seu motivo, ao colocar, por exemplo, em capítulos consecutivos (Gn 1 e 2 ), dois relatos distintos da Criação:

Por que o autor não modificou as narrativas a fim de suavizar as contradições? (...) Se pudermos evitar o provincianismo hodierno de presumir que os autores antigos devem ser simples porque são antigos, talvez seja possível entender que o autor do Gênese escolheu combinar as duas versões da criação do mundo exatamente porque compreendeu que seu objeto era profundamente contraditório e resistente a uma exposição linear e uniforme, e que aquela era a maneira conveniente de lhe dar a expressão literária mais justa. (ALTER, 2007, p. 218. Grifo meu.).

Semelhantemente ao relato da Criação, temos a dupla narrativa do personagem Davi. Em I Samuel 16, Davi é apresentado como um pastor e músico, escolhido por Deus para ser um rei. No capítulo seguinte, em I Samuel 17, ele é um guerreiro e sanguinário que mata Golias. Duas narrativas distintas de uma mesma pessoa/personagem. Para Alter, essa arte compósita da Bíblia é como a arte cubista:

O olho normal jamais conseguiria enxergar as duas perspectivas no mesmo tempo, mas é uma prerrogativa do pintor representá-la como uma percepção simultânea na composição de sua pintura (...) Deus é a um só tempo transcendente e imanente (...), tão absoluto em Sua onipotência quanto ativa e empaticamente comprometido com Sua criação. (ALTER, 2007, p. 219).

O texto bíblico é também existencial, pois questiona os temas da fé, da inconsistência, da dúvida, da vida, da morte, do pecado, do sofrimento, da liberdade humana.

Para Frye, o texto bíblico "está por trás” de toda tradição cultural e literária do Ocidente, como já foi dito: "O crescente descaso pela Bíblia em nossa época secularizada abriu um hiato entre ela [a Bíblia] e nossa literatura em geral, uma lacuna de ignorância que deve, em certa medida, adulterar esta última”(ALTER; KERMODE, 1997, p. 13). Por isso se faz necessário pensar "uma nova concepção da Bíblia como obra de grande força e autoridade literária, obra sobre a qual se pode perfeitamente acreditar que tenha podido moldar as mentes e vidas de homens e mulheres inteligentes por mais de dois milênios" (ALTER; KERMODE, 1997, p. 12). 
As narrativas bíblicas também podem ser estudadas por métodos desenvolvidos na crítica literária:

Como Hans-Georg Gadamer afirmou, o crítico histórico está sempre colocando no texto algo que não é o texto, algo que o texto por si mesmo não procura fornecer; 'ele vai sempre para trás [dos textos] e do significado que eles expressam (...). Mas é possivel se interessar pelo texto e pelo seu próprio significado; isto é crítica literária propriamente dita. (KERMODE, 1997, p. 648. Grifo meu).

A análise literária da Bíblia não tem, necessariamente, uma finalidade teológica e edificante. Os leitores que interpretam a Bíblia à luz da fé religiosa podem encontrar instrução juntamente com aqueles que desejam compreender seu lugar em uma cultura secularizada.

\section{Considerações Finais}

A Bíblia possui uma estrutura complexa de narrativas, imagens, metáforas e símbolos. Como texto literário, a Bíblia não é fechada e definida aos círculos religiosos, mas aberta e livre.

As ambiguidades e contradições estão fortemente presentes na narrativa bíblica e o editor faz questão de revelá-las. Assim, é possível enxergar a tensão dialética presente na Bíblia: o relativo e o absoluto; a imperfeição humana e a perfeição divina; o caos da experiência histórica e a promessa de um projeto divino para a história. É justamente o senso de contradição e de desordem que enriquecem a narrativa bíblica, tornando profunda a sua visão sobre a natureza humana e o mundo. A narrativa bíblica é um conjunto de textos em diálogo inquieto uns com os outros. A força do texto bíblico na cultura e em outras literaturas é uma realidade que precisa ser percebida e melhor explorada.

\section{Referências bibliográficas}

ALTER, Robert; KERMODE, Frank (orgs). Guia literário da Bíblia. Trad. Raul Fiker; revisão de tradução de Gilson César Cardoso de Souza. São Paulo: Fundação Editora da UNESP, 1997.

ALTER, Robert. A arte da narrativa bíblica. Trad. Vera Pereira. São Paulo: Companhia das Letras, 2007.

ALVES, Rubem. O que é religião. 15. ed. São Paulo: Brasiliense, 1992.

ALVES, Rubem. Lições de feitiçaria: meditações sobre a poesia. São Paulo: Loyola, 2003.

AUERBACH, Erich. A Cicatriz de Ulisses. In: AUERBACH, Erich. Mimesis: a representa- 
ção da realidade na literatura ocidental. São Paulo: Perspectiva, 2009.

BÍBLIA. Português. Bíblia sagrada. 2. ed. Trad. João Ferreira de Almeida. Edição revista e atualizada. Barueri, SP: Sociedade Bíblica do Brasil, 1993.

CAMPOS, Haroldo de. Bere'shith - a cena da origem (e outros estudos de poética bíblica). São Paulo: Perspectiva, 2000.

GOLIN, Luana Martins. A Bíblia como texto literário: uma leitura a partir de Northrop Frye. In: RIBEIRO, Cláudio; FONSECA, Hugo (orgs). Teologias e Literaturas 2: aproximações entre religião, Teologia e Literatura. São Paulo: Fonte Editorial, 2013, p. 49-68.

GOLIN, Luana Martins. Entre textos, diálogos e vozes: aspectos teóricos e metodológicos. In: GOLIN, Luana Martins. O Evangelho segundo Dostoiévski: uma abordagem intertextual da imagem de Cristo no romance O Idiota. São Paulo: Terceira Via, 2015, p. 23-84.

STEINER, George. Depois de Babel: questões de linguagem e tradução. 3. ed. Trad. Alberto Faraco. Curitiba: Editora da UFPR, 2005. 